\title{
STRUCTURAL DISORDER AND TRANSPORT IN TERNARY OXIDES WITH THE PYROCHLORE STRUCTURE
}

\author{
Final Report \\ Contract \# DE-FG02-86ER45261.A010
}

Period 1 July 1998 through 30 June 2000

\begin{abstract}
Submitted by
Professor Harry L. Tuller, Principal Investigator

Department of Materials Science and Engineering

Massachusetts Institute of Technology

Cambridge MA 02139
\end{abstract}

Tel (617) 253-6890, Fax (617) 258-5749, E-mail tuller@mit.edu

to

Basic Energy Sciences Division

Department of Energy

17 June 2001

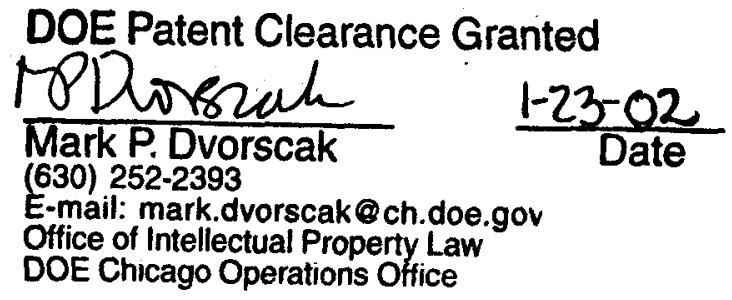




\section{DISCLAIMER}

This report was prepared as an account of work sponsored by an agency of the United States Government. Neither the United States Government nor any agency thereof, nor any of their employees, makes any warranty, express or implied, or assumes iny legal liability or responsibility for the accuracy, completeness, or usefulness of any information, apparatus, product, or process disclosed, or represents that its use would not infringe privately owned rights. Reference herein to any specific commercial produet, process, or service by trade name, trademark, manufacturer, or otherwise does not necessarily constitute or imply its endorsement, recommeadation, or favoring by the. United States Governmeat or any ageacy thereof. The views and opinions of authors expressed herein do not necessarily state or reflect those of the United States Governmeat or any agency thereof. 


\section{DISCLAIMER}

Portions of this document may be illegible in electronic image products. Images are produced from the best available original document. 
RESEARCH ACCOMPLISHMENTS: 1 July 1998 - 30 June 2000

\section{Introduction:}

This research program has focused on the structure- electrical property relations in families of pyrochlore compounds which exhibit, on the one hand, controlled levels of structural disorder and, on the other, controlled levels of ionic and electronic conductivities. Models have been developed to evaluate the often complex defect chemistry of these systems. Much progress has been made in extracting key thermodynamic and kinetic data. From a technological standpoint, novel solid electrolytes and compatible mixed conducting electrodes have been identified and the concept of the single phase monolithic fuel cell design has been demonstrated and patented. Related work on lanthanum gallate-based perovskites has shown even more promising results for use of such materials in the monolithic fuel cell structures. Recent work on the $\mathrm{Bi}_{3} \mathrm{Zn}_{2} \mathrm{Sb}_{3} \mathrm{O}_{14}$ Pyrochlore, a phase found at grain boundaries in varistors, was also completed. This material was found to be a mixed ionic-electronic conductor with interesting implications for grain boundary equilibration kinetics in $\mathrm{ZnO}$-based varistor materials. Three of the most recent projects are summarized below. The results of work on the perovskites are reported in recent publications listed below.

\section{H. Takamura and H.L. Tuller, "Ionic Conductivity of $\mathrm{Gd}_{2} \mathrm{GaSbO}_{7}-\mathrm{Gd}_{2} \mathrm{Zr}_{2} \mathrm{O}_{7}$ Solid Solutions with Structural Disorder", Solid State Ionics, 134, 67-73 (2000).}

Pyrochlore compounds, $\mathrm{A}_{2} \mathrm{~B}_{2} \mathrm{O}_{7}$, are considered to be promising candidates as either electrodes or electrolytes for use in solid oxide fuel cells. Pyrochlores exhibit compositional flexibility, unavailable in conventional solid electrolytes such as yttria stabilized zirconia, which enable control of the ratio of ionic and electronic conductivity, of importance in the above application. In the pyrochlores, the A- and B-sites are normally occupied by larger cations such as the rare-earth elements, and smaller cations including most transition metal cations, respectively. 
$\mathrm{Gd}_{2} \mathrm{Ti}_{2} \mathrm{O}_{7}$ (GT) doped with acceptors or donors shows a range of interesting electrical properties; Ca-doped GT exhibits an ionic conductivity $\left(\sigma_{\mathfrak{i}}\right)$ approaching $10^{-1} \mathrm{~S} / \mathrm{cm}$ at $1000{ }^{\circ} \mathrm{C}$ with an ionic transference number close to unity. Mo-doped GT, on the other hand, is a mixed ionic and electronic conductor (MIEC) in which the electronic conductivity $\left(\sigma_{e}\right)$ reaches values as high as $10^{2} \mathrm{~S} / \mathrm{cm}$ and ionic conductivities $\sigma_{i}$ of

$10^{-2}$ to $10^{-1} \mathrm{~S} / \mathrm{cm}$ at $1000^{\circ} \mathrm{C}$. The electrical conductivity of GT may also be modified by changing the ratio of the ionic radii on the A- and B-sites by forming solid solutions. Although GT itself is an ordered pyrochlore in which intrinsic oxygen "vacancies" are residing only on $8 \mathrm{~b}$ crystallographic sites and immobile, the incorporation of larger cations such as $\mathrm{Zr}$ leads to the disordering of the oxygen sublattices. As a result of the structural disorder, the oxygen ionic conductivity increase by orders of magnitude. In fact, structurally disordered $\mathrm{Gd}_{2}\left(\mathrm{Ti}_{1-\mathrm{x}} \mathrm{Zr}_{\mathrm{x}}\right)_{2} \mathrm{O}_{7}$ (GTZ) is a well-known oxygen ion conductor, exhibiting $\sigma_{i}$ of $10^{-2} \mathrm{~S} / \mathrm{cm}$ at $1000^{\circ} \mathrm{C}$. Structural disorder and resultant enhancement of the ionic conductivity are also observed in the $\mathrm{Gd}_{2} \mathrm{Sn}_{1-}$ $\left.\mathrm{x} \mathrm{Zr}_{\mathrm{x}}\right)_{2} \mathrm{O}_{7}$ (GSZ) system but at a much reduced level.

While the relative radii of the $\mathrm{A}$ and $\mathrm{B}$ cations are known to influence structural disorder on both cation and anion sublattices, and consequently the ionic conductivity, it is of interest to examine the role of the specific cationic species on these pyrochlores. Given that $\mathrm{Ga}^{3+}\left(\mathrm{r}_{\mathrm{Ga}}+\right.$ $=0.620 \AA)$ and $\mathrm{Sb}^{5+}\left(\mathrm{r}_{\mathrm{Sb} 5+}=0.60 \AA\right)$ provides nearly the identical average B-site radius as $\mathrm{Ti}^{4+}\left(\mathrm{r}_{\mathrm{Ti} 4+}=0.605 \AA\right)$, comparison of $\mathrm{Gd}_{2}(\mathrm{GaSb})_{1-\mathrm{x}} \mathrm{Zr}_{2 \mathrm{x}} \mathrm{O}_{7}$ (GGSZ) with the GTZ and GSZ systems provides an opportunity to examine the relative importance of the local B-site chemistry and charge $(3+, 5+$ or $4+)$ in influencing disorder and mass transport in oxide pyrochlores. As in the GTZ system, the ionic conductivity of the GGSZ solid solutions is expected to be enhanced as the larger $\mathrm{Zr}^{4+}\left(\mathrm{r}_{\mathrm{Zr} 4+}=0.72 \AA\right)$ substitute for the smaller GaSb couple.

In this program, we investigated the electrical conductivity of the $\mathrm{Gd}_{2}(\mathrm{GaSb})_{1-\mathrm{x}} \mathrm{Zr}_{2 \mathrm{x}} \mathrm{O}_{7}$ system with $\mathrm{x}=0.2,0.4,0.6$, and 0.8 , as functions of temperature and 
oxygen partial pressure. These data were analyzed with respect to an appropriate defect model with emphasis on evaluating the oxygen ion conductivity.

of $\mathrm{Zr}^{4+}$ for $(\mathrm{Ga}, \mathrm{Sb})$ in $\mathrm{Gd}_{2} \mathrm{GaSbO}_{7}$ leads to increased structural disorder as observed as well in GTZ and GSZ

The ionic conductivity and structural disorder of $\mathrm{Gd}_{2} \mathrm{GaSbO}_{7}-\mathrm{Gd}_{2} \mathrm{Zr}_{2} \mathrm{O}_{7}$ (GGSZ) solid solutions were investigated and GGSZ with $\mathrm{x}=0.4,0.6$, and 0.8 exhibited ionic conductivities of $2.52 \times 10^{-6}, 3.56 \times 10^{-5}$, and $2.14 \times 10^{-3} \mathrm{~S} / \mathrm{cm}$ at $1000{ }^{\circ} \mathrm{C}$, respectively. The corresponding activation energies for ionic conduction were $1.85,1.17$, and $0.51 \mathrm{eV}$, respectively.

From the defect model fitting, it was found that (1) only the oxygen Frenkel enthalpy depended strongly on composition, rapidly decreasing with increasing $\mathrm{x}$, and reaching to $\approx 0 \mathrm{eV}$ at $x=0.8$; (2) both the concentration and mobility of oxygen vacancies exhibited a dependence on $\mathrm{Zr}$ content; (3) in comparison with the GTZ and GSZ systems, the simultaneous change in oxygen vacancy concentration and mobility gave the sharpest composition dependence of the ionic conductivity and activation energy. 


\section{J.J. Sprague and H.L. Tuller, "Mixed Ionic and Electronic Conduction in Mn/Mo Doped Gadolinium Titanate", J. Euro. Ceram. Soc., 19, 803-806 (1999).}

Our past work has shown that $\mathrm{Gd}_{2}\left(\mathrm{Ti}_{1-x} \mathrm{Mo}_{\mathrm{x}}\right)_{2} \mathrm{O}_{7}$ (Mo doped GT) exhibits high levels of mixed conduction under reducing atmospheres, making it suitable as an anode in a Solid Oxide Fuel Cell. It decomposes at high $\mathrm{P}_{\mathrm{O} 2}$, however. We have recently succeeded in extending the stability limits of GT-Mo to higher $P_{02}$ with the addition of $\mathrm{Mn}$. Our earlier studies on $\mathrm{Gd}_{2}\left(\left(\mathrm{Moy}_{\mathrm{y}} \mathrm{Mn}_{1}\right.\right.$ y) Ti $\left._{1-x}\right)_{2} \mathrm{O}_{7}$ (GMMT) as a function of $\mathrm{P}_{\mathrm{O} 2}, \mathrm{~T}$, and composition utilizing impedance spectroscopy and $\mathrm{x}$-ray diffraction were extended to include the joint effects of variations in $\mathrm{x}$ and $\mathrm{y}$ on the conductivity and stability of the material under cathodic environments. Defect models explaining the dependence of the partial conductivities on oxygen partial pressure, temperature, and composition are presented as well. A more detailed discussion follows.

Electrical conductivity measurements were made on the pyrochlore $\mathrm{Gd}_{2}\left(\left(\mathrm{Mo}_{1-\mathrm{y}} \mathrm{Mn}_{\mathrm{y}}\right)_{\mathrm{x}} \mathrm{Ti}_{1-\mathrm{x}}\right)_{2} \mathrm{O}_{7-\delta}(\mathrm{GMMT})$ as a function of oxygen partial pressure $\left(\mathrm{P}_{\mathrm{O}_{2}}\right)\left(10^{-25}<\mathrm{P}_{\mathrm{O}_{2}}<\right.$ $1 \mathrm{~atm})$, temperature $\left(600^{\circ} \mathrm{C} \leq \mathrm{T} \leq 1000^{\circ} \mathrm{C}\right)$, and composition (x,y). Particular emphasis was placed on the materials value as a mixed ionic and electronic conductor (MIEC). Previous work on the $\mathrm{Gd}_{2}\left(\mathrm{Ti}_{1-\mathrm{x}} \mathrm{Mo}_{\mathrm{x}}\right)_{2} \mathrm{O}_{7}$ system has shown it to have high electronic conductivity $\left(10^{2} \mathrm{~S} / \mathrm{cm}\right)$ with a high minority ionic conductivity (up to $10^{-1} \mathrm{~S} / \mathrm{cm}$ ) for high Mo values under anodic conditions. However, the material decomposes at higher $\mathrm{P}_{\mathrm{O}_{2}}$, due to a sharp increase in oxygen interstitial concentration accompanying the oxidation of $\mathrm{Mo}^{4+}$ to $\mathrm{Mo}^{6+}$. In this study, we investigated the ability of variable valent $\mathrm{Mn}$ to compensate the oxidation of Mo and thereby stabilizing the material to much higher $\mathrm{P}_{\mathrm{O}_{2}}$ while retaining the high conductivity.

The conductivity of GMMT was found to increase by over 4 orders of magnitude by increasing $x$ from 0.01 to 0.3 with $y=0.66$. The peak value in air of $0.2 \mathrm{~S} / \mathrm{cm}$ was obtained at $1000^{\circ} \mathrm{C}$ for the $\mathrm{x}=0.33, \mathrm{y}=0.66$ material. The conductivity was weakly dependent on $\mathrm{y}$, increasing by about $1 / 2$ order of magnitude under oxidizing conditions when increasing $y$ from 0.33 to $0.66(x=0.1)$. The activation energy for the conduction in the characteristic $\mathrm{P}_{\mathrm{O}_{2}}$ 
independent plateau decreased systematically with $\mathrm{x}$ from nearly $1.5 \mathrm{eV}$ at $\mathrm{x}=0.01, \mathrm{y}=0.66$ to $0.64 \mathrm{eV}$ at $\mathrm{x}=0.3, \mathrm{y}=0.66$. All of the compositions were found to be stable pyrochlore up to $1000{ }^{\circ} \mathrm{C}$, the highest temperature used in this study.

A detailed defect model was developed to model and explain the electrical conductivity of GMMT. Our analysis indicates that the material is primarily electronic at all $\mathrm{x}, \mathrm{y}$, with some potential ionic conduction under reducing conditions. The conductivity conforms well to a dilute defect model for $x \leq 0.05$, while at $x \geq 0.1$, the material is suspected to experience defect band hopping conduction within the Mo and Mn levels. The incorporation of defect bands into the defect model is necessary to explain the large jump in conductivity and decrease in activation energy with increasing $x$. Modeling of the conductivity data for $x=0.01$ and $0.05(y=0.66)$ materials yields an estimate for the $\mathrm{Mn}$ ionization energy of $\sim 2.6 \mathrm{eV}$ as well as expressions for the reduction constant, $\mathrm{K}_{\mathrm{r}}=10^{77}\left(\mathrm{~atm}^{1 / 2} \mathrm{~cm}^{-9}\right) \exp (-6.4 \mathrm{eV} / \mathrm{kT})$, and Frenkel constant, $\mathrm{K}_{\mathrm{f}}=10^{53}\left(\mathrm{~cm}^{-6}\right) \exp (-2.9 \mathrm{eV} / \mathrm{kT})$. Similar modeling for the $\mathrm{x}=0.3, \mathrm{y}=0.66$ material yields defect band hopping energies in the $\mathrm{Mn}$ and $\mathrm{Mo}$ defect bands of $0.19 \mathrm{eV}$ and $0.22 \mathrm{eV}$ respectively.

Independent measurements utilizing an electronic blocking cell to separate the ionic and electronic contributions to the conductivity were made for the $\mathrm{x}=0.1, \mathrm{y}=0.66$ composition. The measurements confirm that the material is electronic with an electronic transference number of $0.9-0.95$ under oxidizing environments. The level of the ionic conductivity is on the order of $10^{-2}-10^{-3} \mathrm{~S} / \mathrm{cm}$ at $900^{\circ} \mathrm{C}$.

This work demonstrated the ability to introduce significant electronic conductivity into a large band gap semiconductor with high ionic disorder and thus achieve high levels of mixed ionic-electronic conductivity (MIEC).

The Electrical and Defect Properties of $\mathrm{Bi}_{3} \mathrm{Zn}_{2} \mathrm{Sb}_{3} \mathrm{O}_{14}$ Pyrochlore: A Grain-Boundary Phase in ZnO-Based Varistors, J. Clayton, H. Takamura, R. Metz, H.L. Tuller and B. J. Wuensch, J. Electroceramics, submitted. 
The nonlinear current-voltage relationship exhibited by $\mathrm{ZnO}$ with $\mathrm{Bi}_{2} \mathrm{O}_{3}$ and $\mathrm{Sb}_{2} \mathrm{O}_{3}$ additives forms the basis for its use as a varistor in surge protectors. These additives are used to either aid in sintering $\left(\mathrm{Bi}_{2} \mathrm{O}_{3}\right.$ melts, allowing for liquid phase sintering ) or to control the microstructure ( $\mathrm{Sb}$ derived from $\mathrm{Sb}_{2} \mathrm{O}_{3}$ forms a secondary spinel phase, $\mathrm{Zn}_{7} \mathrm{Sb}_{2} \mathrm{O}_{12}$, which controls growth of the $\mathrm{ZnO}$ grains.) These oxide additions also result in the formation of another secondary grain boundary phase: a pyrochlore shown to have composition $\mathrm{Bi}_{3} \mathrm{Zn}_{2} \mathrm{Sb}_{3} \mathrm{O}_{14}$. While there have been investigations of the morphology and the electronic properties of interfaces that contain the phase, the preparation of $\mathrm{Bi}_{3} \mathrm{Zn}_{2} \mathrm{Sb}_{3} \mathrm{O}_{14}$ in the form of a homogeneous single-phase powder is difficult and so, only limited studies have been made of its bulk properties to date The first equilibrium transport studies of $\mathrm{Bi}_{3} \mathrm{Zn}_{2} \mathrm{Sb}_{3} \mathrm{O}_{14}$ pyrochlore were completed and have indicated it to be a mixed ionic-electronic conductor. This is supported by the $\mathrm{Po}_{2}$ dependence of the conductivity and the shallow minimum where $p$-type conduction switches to $n$-type conduction. This mixed conduction is also confirmed by both the ionic transference number measurements and the electrical conductivity results which were fitted to the defect model developed in this study. Assuming a model where the Frenkel defects are dominant the data, one obtains an estimate of the band gap equal to $3.1 \mathrm{eV}$..

\section{Recent Publications-DOE Program}

Books:

Oxygen Ion and Mixed Conductors and their Technological Applications: Proceedings of NATO Adv. Study Inst., eds. H.L. Tuller, J. Schoonman, and I. Riess, July 15-30, 1997, Erice, Italy, Kluwer Academic Publishers, The Netherlands, in print.

Interfacially Controlled Functional Materials; Electrical and Chemical Properties, eds. J. Maier and H.L. Tuller, North Holland, Amsterdam, 2000. Also published in the journal: Solid State Ionics, 131 [1-2], 1-210 (2000). 


\section{Publications-Refereed Journals:}

T.H. Yu and H.L. Tuller, "Electrical Conduction and Disorder in the Pyrochlore System (Gd1$\left.{ }_{\mathrm{x}} \mathrm{Cax}_{\mathrm{x}}\right)_{2} \mathrm{Sn}_{2} \mathrm{O}_{7}$ ", J. Electroceram., 2, 49-55 (1998).

J.J. Sprague and H.L. Tuller, "Mixed Ionic and Electronic Conduction in Mn/Mo Doped Gadolinium Titanate", J. Euro. Ceram. Soc., 19, 803-806 (1999)

N.J. Long, F. Lecarpentier and H.L. Tuller, "Structure and Electrical Properties of Ni-substituted Lanthanum Gallate Perovskites", J. Electroceramics, 3:4, 399-407 (1999).

F. Lecarpentier, H.L. Tuller and N. Long, "Performance of $\mathrm{La}_{0.9} \mathrm{Sr}_{0.1} \mathrm{Ga}_{0.5} \mathrm{Ni}_{0.5} \mathrm{O}_{3}$ as a Cathode for a Lanthanum Gallate Fuel Cell”, J. Electroceram. 5:3, 225-230 (2000)

H. Takamura and H.L. Tuller, "Ionic Conductivity of $\mathrm{Gd}_{2} \mathrm{GaSbO}_{7}-\mathrm{Gd}_{2} \mathrm{Zr}_{2} \mathrm{O}_{7}$ Solid Solutions with Structural Disorder", Solid State Ionics, 134, 67-73 (2000).

J. Clayton, H. Takamura, R. Metz, H.L.Tuller and B. J. Wuensch, "The Electrical and Defect Properties of $\mathrm{Bi}_{3} \mathrm{Zn}_{2} \mathrm{Sb}_{3} \mathrm{O}_{14}$ Pyrochlore: A Grain-Boundary Phase in $\mathrm{ZnO}$-Based Varistors", J. Electroceramics, submitted.

\section{Publications-Proceedings:}

J.J. Sprague, O. Porat and H.L. Tuller, "Conductivity and Stability of $\mathrm{Gd}_{2}\left(\left(\mathrm{Mo}_{1 / 3} \mathrm{Mn}_{2 / 3}\right)_{\mathrm{x}}\right)_{2} \mathrm{O}_{7}$ " in Electrically Based Microstructural Characterization II (MRS vol. 500), Editors, R. Gerhardt, M. Alim and S.R. Taylor, Materials Research Society, Warrendale, PA, 1998, pp. 321-326.

N.J. Long and H.L. Tuller, "Mixed Ionic-Electronic Conduction in Ni-Doped Lanthanum Gallate Perovskites", in Materials for Electrochemical Energy Storage and Conversion II - Batteries, 
DE-FG02-86-ER45261, Final Report

17 June 2001

Page 8

Capacitors and Fuel Cells, (MRS vol. 496) Editors, D. Ginley, D. Doughty, B. Scrosati, T.

Takamura, and Z. Zhang, Materials Research Society, Warrendale, PA, 1998, pp.129-137.

O. Porat, N. Long and H.L. Tuller, "Mixed Ionic-Electronic Conduction in Mn Doped

Gadolinium Titanate Pyrochlore", in Ionic and Mixed Conducting Ceramics III, ECS

Symposium Proceedings, Vol. 97-24, eds. T.A. Ramanarayanan, W.L. Worrell, and H.L. Tuller, A.C. Khandkar, M. Mogensen and W. Gopel, Paris, France, The Electrochemical Society, Pennington, NJ, 1998, p. 350-362.

J.J. Sprague and H.L. Tuller, "Mixed Ionic and Electronic Conduction in Mn/Mo Doped Gadolinium Titanate", Solid State Ionics V(MRS Proc.Vol. 548), G.-A. Nazri, C. Julien, and A. Rougier, eds. Materials Research Society, Warrendale, PA, 1999, pp.527-532.

H. Takamura and H.L. Tuller, "The Synthesis and Electrical Conductivity of Novel Mixed Ionic and Electronic Conductors in the $\mathrm{Gd}_{2} \mathrm{GaSbO}_{7}-\mathrm{Gd}_{2} \mathrm{Zr}_{2} \mathrm{O}_{7}$ Solid Solution", Solid State Ionics V(MRS Proc.Vol. 548), G.-A. Nazri, C. Julien, and A. Rougier, eds. Materials Research Society, Warrendale, PA, 1999, pp.539-543.

H.L. Tuller, "Defects and Transport: Implications for Solid Oxide Electrolytes and Mixed Conductors," Oxygen Ion and Mixed Conductors and their Technological Applications: Proceedings of NATO Adv. Study Inst., eds. H.L. Tuller, J. Schoonman, and I. Riess, July 15-30, 1997, Erice, Italy, Kluwer Academic Publishers, The Netherlands, in print.

H.L. Tuller, "Materials Design and Optimization," Oxygen Ion and Mixed Conductors and their Technological Applications: Proceedings of NATO Adv. Study Inst., eds. H.L. Tuller, J. Schoonman, and I. Riess, July 15-30, 1997, Erice, Italy, Kluwer Academic Publishers, The Netherlands, in print. 


\section{Honors, Awards and Appointments:}

Recipient of Alexander von Humbolt Award 1997-2002

Editor-in-chief : Journal of Electroceramics

Series Editor: Electronic Materials: Science and Technology, Kluwer Academic Publishers

Member, External Advisory Committee, University of Maryland MRSEC

Member, International Advisory Board, Department of Materials Science, University of Patras, Greece 